\title{
Formaldehyde-related clinical symptoms reported by medical students during gross anatomy cadaver dissection
}

\author{
Subiektywne objawy kliniczne u studentów medycyny związane z ekspozycją \\ na formaldehyd podczas zajęć prosektoryjnych z anatomii
}

\author{
Łukasz Pietrzyk', Anna Torres², Marta Denisow-Pietrzyk', Ryszard Maciejewski², Kamil Torres' \\ 'Department of Didactics and Medical Simulation, Chair of Anatomy, Medical University of Lublin, Lublin, Poland \\ ${ }^{2}$ Chair and Department of Human Anatomy, Medical University of Lublin, Lublin, Poland
}

\section{KEY WORDS:}

formaldehyde, medical students, cadaver, dissection, gross anatomy.

\section{SŁOWA KLUCZOWE:}

formaldehyd, studenci medycyny, zwłoki, preparowanie, anatomia.
ADDRESS FOR CORRESPONDENCE:

Łukasz Pietrzyk MD, PhD

Department of Didactics

and Medical Simulation

Chair of Anatomy

Medical University of Lublin

4 Jaczewskiego St

20-094 Lublin, Poland

phone: +48505918 705

e-mail: lukasz.pietrzyk@wp.pl

\begin{abstract}
Introduction. Formaldehyde is a noxious gas used as a tissue preservative of cadavers in autopsy rooms. Therefore, exposure to higher concentrations applies particularly to laboratory staff, anatomists and medical students. Prolonged exposure to formaldehyde is associated with clinical complications.
\end{abstract}

Objective. To assess whether exposure to repeated inhalation of low concentrations of formaldehyde (FA) experienced during a gross anatomy course triggers subjective clinical symptoms in medical students.

Material and methods. All 198 first-year medical students of the Medical University of Lublin, Poland (28\% with allergy history and $72 \%$ without allergy history; $69 \%$ male and $31 \%$ female) responded to a questionnaire concerning their subjective FA-related clinical symptoms. Differences in proportions of experienced symptoms between allergic vs. nonallergic, and female vs. males were compared by the Mann-Whitney $U$ test.

Results. Even though formaldehyde concentrations in the gross anatomy laboratory were relatively low $\left(0.47-0.57 \mathrm{mg} / \mathrm{m}^{3}\right)$, medical students experienced various reactions (lacrimation in $85.9 \%$, red eyes, dry and itchy eyes, runny nose, sneezing, and headache in $>50 \%$ of students, cough in $44 \%$, and dry throat or throat irritation in $42 \%$ of students). Among students with a history of allergy, eye, nose, skin and respiratory system symptoms occurred more frequently in comparison to nonallergic students. Female individuals demonstrated higher sensitivity to FA exposure.

Conclusions. Exposure to formaldehyde may result in development of clinical symptoms in medical students. Particularly unpleasant symptoms may be experienced by individuals with allergy history. It is necessary to decrease formaldehyde concentrations in the anatomy dissection laboratory.

\section{STRESZCZENIE}

Wprowadzenie. Formaldehyd to szkodliwa substancja chemiczna, której wodny roztwór jest powszechnie stosowany jako środek konserwujący w prosektoriach anatomicznych. Osobami szczególnie narażonymi na ekspozycję na formaldehyd są studenci medycyny oraz per- 
sonel laboratoryjny. Długotrwała ekspozycja na formaldehyd często wiąże się z pojawieniem się różnorodnych objawów klinicznych.

Cel pracy. Ocena subiektywnych objawów klinicznych u studentów medycyny, którzy byli narażeni na wdychanie formaldehydu w niskim stężeniu podczas kursu anatomii.

Materiał i metodyka. Stu dziewięćdziesięciu ośmiu studentów pierwszego roku medycyny ( $28 \%$ z alergią $\mathrm{w}$ wywiadzie i $72 \%$ bez historii alergii; $69 \%$ mężczyzn i 31\% kobiet) uczestniczyło w badaniu przeprowadzonym za pomocą ankiety dotyczącej subiektywnych objawów klinicznych związanych z ekspozycją na formaldehyd. Analiza różnic w częstości występowania objawów klinicznych pomiędzy alergikami i osobami bez alergii oraz pomiędzy mężczyznami i kobietami została przeprowadzona przy użyciu testu U Manna-Whitneya.

Wyniki. Pomimo niskiego stężenia formaldehydu w salach prosektoryjnych $\left(0,47-0,57 \mathrm{mg} / \mathrm{m}^{3}\right)$ studenci medycyny doświadczali różnorodnych objawów klinicznych. Łzawienie obserwowano u 85,9\% studentów, zaczerwienienie oczu, suchość i swędzenie oczu, katar, kichanie i ból głowy u ponad 50\% studentów, natomiast kaszel oraz suchość lub podrażnienie gardła u odpowiednio $44 \%$ i $42 \%$ studentów. U studentów z alergią w wywiadzie częściej występowały objawy dotyczące oczu, nosa, skóry i układu oddechowego w porównaniu ze studentami bez alergii. U kobiet stwierdzono większą wrażliwość na ekspozycję na formaldehyd w porównaniu z mężczyznami.

Wnioski. Ekspozycja na formaldehyd może spowodować u studentów medycyny rozwój objawów klinicznych. Szczególnie nieprzyjemnych objawów mogą doświadczać osoby $\mathrm{z}$ alergią $\mathrm{w}$ wywiadzie. W celu zmniejszenia działań niepożądanych formaldehydu konieczne jest zmniejszenie jego stężenia w prosektoriach anatomicznych.

\section{INTRODUCTION}

Formaldehyde (formalin, FA) is a noxious, flammable gas which was discovered in 1856 by August Wilheld Von Hofmann [1]. Since then, formalin has been used in many branches of industry (chemical, textile, cosmetic, wood). Formaldehyde may be present in a variety of ordinary consumer goods and emitted from many products, e.g. building materials, resins, glues, fiberboard, paper, fabrics, and household cleaning products [2]. Prolonged exposure to formaldehyde is commonly associated with both allergic and non-allergic systemic complications [3]. Formaldehyde toxicity is related to mucosa irritation, particularly to the eyes and to the upper respiratory tract $[4,5]$. Acute clinical symptoms include headache, dermatitis, and asthma [6]. In sensitive individuals, acute symptoms can be observed at a very low concentration of FA $\left(0.012 \mathrm{mg} / \mathrm{m}^{3}\right)$. Exposure to concentrations of about $1 \mathrm{ppm}\left(1.23 \mathrm{mg} / \mathrm{m}^{3}\right)$ can cause watering of the eyes and irritation of the upper respiratory passages (e.g. a cough). Higher levels (10$20 \mathrm{ppm} ; 12.5-25 \mathrm{mg} / \mathrm{m}^{3}$ ) may induce tightening in the chest, a sense of pressure in the head, and pal- pitations [2]. Formalin is commonly used in some medical branches and research, e.g., as a tissue preservative of cadavers in autopsy rooms. Therefore, exposure to higher concentrations applies mainly to laboratory staff, anatomists and paramedical workers $[7,8]$. The process of embalming in a mixture of formalin, fixatives, preservatives, germicides, buffers, wetting agents, anticoagulants, dyes, and perfuming agents aims to stop decomposition of cadavers and help to maintain proper anatomical conditions [9].

The gross anatomy course is the core course during preclinical training in medical universities worldwide [10]. The course program includes fresh cadaver dissections or prosections [11, 12]. During these dissection classes, medical and dental students are exposed to formaldehyde vapors emitted from cadavers $[3,4]$. Inhalation is considered to be the primary route of exposure; however, the area of formalin absorbance includes the lungs, gastrointestinal tract, and skin [13, 14]. Several reports have evidenced that formalin inhibits learning and hinders memory abilities in mice $[15,16]$. A relationship between formaldehyde inhalation and increased incidence of nasal squamous cell carcinomas in animals (rats and 
B6C3F1 mice) has been revealed [17]. Although humans and animals may differ in their susceptibility to specific cancer-causing agents, the International Agency for Research on Cancer classified formaldehyde as a group 1 human carcinogen $15[2,18]$. The genotoxic and mutagenic abilities of formaldehyde are probably related to the formation of DNA-protein crosslinks (DPC) in target tissues [19]. Formation of DPC in the nasal respiratory mucosa due to chronic inhalation of formaldehyde has been evidenced [20]. Epidemiological studies revealed evidence for the carcinogenicity of formalin and reported that industrial workers who are exposed to formaldehyde or formaldehyde-containing products are at increased risk of nasopharyngeal and hypopharyngeal cancers $[17,21,22]$. However, there was no association with the highest formaldehyde exposure and lung cancer or leukemia [23, 24].

\section{OBJECTIVE}

The aim of the study was to assess whether exposure to repeated inhalation of a low level of FA experienced during a gross anatomy course triggers subjective clinical symptoms in medical students.

\section{MATERIAL AND METHODS}

The study was performed in the Department of Human Anatomy, Medical University of Lublin, Poland. The study population consisted of the first-year medical students, the participants of a gross anatomy course with cadaver dissection as part of the laboratory classes. Laboratory rooms measured $5.5 \times 7.2$ $\times 3.5 \mathrm{~m}$ and had one door and two windows. Each anatomy dissection room had general ventilation and was equipped with one stainless steel dissecting work table. All anatomy dissection rooms fulfilled the requirements of the National Labor Inspectorate. Atmospheric formaldehyde concentration levels, detected by high-performance liquid chromatography, were $0.47-0.57 \mathrm{mg} / \mathrm{m}^{3}$, i.e. within the range of indoor air limit values for FA emissions in Poland set by the Ministry of Labor and Social Policy (Regulation from 29 November 2002; Dz. U. Nr 217, poz. 1833).

In total, 198 first-year medical students completed the questionnaire survey. Among all participants, 69 were male and 129 female, with the age range 19-22 years. The mean duration of formalin exposure was $4 \mathrm{~h}$ per week during the course lasting for 30 weeks (15 weeks in fall and 15 weeks in the spring semester).

The questionnaire was distributed after the objective structured examination in anatomy (OSEA) at the end of the gross anatomy course in June 2015. Before the investigations, each participant was in- formed about the aim of the study and agreed to answer the questionnaire completely anonymously. A three-section questionnaire was developed. The first section included questions about demographic factors and allergy history. The second part consisted of questions related to 24 subjective allergy symptoms experienced after the gross anatomy course. We evaluated the symptoms relating to: (i) eyes: redness, dryness and itching, excessive lacrimation, deterioration in eyesight; (ii) nose: runny nose, nose bleeding, sneezing, alterations in odor perception; (iii) respiratory system: dry throat and throat irritation, cough, respiratory distress; (iv) digestive system: nausea, vomiting, lack of appetite, GI disturbances, increased appetite, excessive salivation; (v) nervous system: headache, prolonged sleeping time, decreased perception; (vi) skin: rash, dryness and itching, redness; and (vii) general symptom: fatigability. The symptoms were assessed using a 5-point Likert scale $(1=$ poor, 2 = below moderate, $3=$ moderate, 4 = above moderate, 5 = strong). The third section evaluated the influence of formalin on learning and memory processes and included four multiple choice questions with three possible options.

\section{Statistical analysis}

For statistical purposes, the study population was divided (i) by allergy history (with allergy history vs. without allergy history), and (ii) by sex (male vs. female). Differences between groups of respondents were analyzed using the Mann-Whitney $U$ test. Differences of $p$ less than 0.05 were considered to be significant. Statistical analysis was performed using SPSS version 16.0 (SPSS, Inc., Chicago, IL, USA).

\section{RESULTS}

The characteristics of the study group are shown in Table 1. All 198 students responded to the questionnaires. The mean age of respondents was 20.40 \pm 1.46 years; the majority were female $(n=129)$. There were no significant differences in mean age between males and females. Fifty-six (28.3\%) students reported an allergy history, including 28 (14.1\%) with hay fever, $16(8.1 \%)$ with alimentary allergy and 11 (5.6\%) with atopic dermatitis.

All the students reported the smell of formaldehyde in the anatomy dissection room. Most of the respondents $(80 \%)$ found the moderate unpleasant odor of FA not affecting the class performance and students' achievements. Irrespective of the study group, the students stated that these symptoms did not occur in other buildings of the campus.

Excessive lacrimation (170; 85.9\%) after exposure to FA in the anatomy dissection room was the most frequently reported. Red, dry and itchy eyes, run- 
Table I. Characteristics of the study group and the type of allergy symptoms reported by students with an allergy history

Tabela I. Charakterystyka grupy badanej i typy objawów alergicznych u studentów medycyny z alergiq w wywiadzie

\begin{tabular}{lccc} 
Parameter & $\begin{array}{c}\text { Total population } \\
(N=198)\end{array}$ & $\begin{array}{c}\text { Male } \\
(N=69)\end{array}$ & $\begin{array}{c}\text { Female } \\
(N=129)\end{array}$ \\
\hline Age, mean \pm SD [years] & $20.40 \pm 1.46$ & $20.33 \pm 1.75$ & $20.43 \pm 1.29$ \\
\hline Students with allergy history, $n(\%)$ & $56(28.3)$ & $12(17.4)$ & $44(34.1)$ \\
\hline Type of allergy symptoms, $n(\%):$ & & & $21(16.3)$ \\
\hline Hey fever & $28(\mid 4.1)$ & $7(10.1)$ & $13(10.1)$ \\
\hline Alimentary allergy & $16(8.1)$ & $3(4.3)$ & $10(7.8)$ \\
\hline Atopic dermatitis & $11(5.6)$ & $1(1.4)$ & $10(7.8)$ \\
\hline Allergic conjunctivitis & $10(5.1)$ & $0(0.0)$ & $5(3.9)$ \\
\hline Bronchial asthma & $6(3.0)$ & $1(1.4)$ & $3(2.3)$ \\
\hline Hives & $3(1.5)$ & $0(0.0)$ & \\
\hline
\end{tabular}

ny nose, sneezing, and headache were commonly noted subjective symptoms (in $>50 \%$ of students). Among respiratory system related symptoms, cough $(44 \%)$ and dry throat or throat irritation $(42 \%)$ were frequently present. Digestive system symptoms were experienced only by $6.6 \%$ (vomiting) to $23 \%$ (increased appetite) of participants. Skin problems were experienced by $<20 \%$ of students. Only a few students $(13 ; 6.6 \%)$ complained of nose bleeding.

Students with allergy history revealed significantly higher occurrence of a runny nose and sneezing in comparison to students without allergy history; allergic vs. nonallergic - $66.1 \%$ vs. $51.4 \%$ for a runny nose; $67.9 \%$ vs. $50.0 \%$ for sneezing (Fig. 1 ).

The subjective reactions to FA were primarily below moderate to moderate severity; however, students with allergy history reported more intensive symptoms related to eyes, nose, respiratory system, and skin compared to students without allergy history (Table 2).

No significant differences in the frequency of reported subjective clinical symptoms were observed between females and males, but symptoms related to eyes, nose and the digestive tract reported by females were more severe (Table 3 ).

\section{DISCUSSION}

In Poland, new teaching methods, e.g. medical simulation and problem-based learning, have been implemented into gross anatomy courses [10,11]. However, the traditional methodology of anatomy teaching, including cadaveric dissections or prosections, remains an integral part of the curriculum, and both medical and dental students cannot proceed to the next step of their education without this practice [9]. During the gross anatomy course, our students are subjected to repeated inhalation of formaldehyde. Although the atmospheric formaldehyde concentration levels were within the range of indoor air limit values accepted in Polish law, our students experienced various clinical symptoms after the exposure to FA. The most common undesirable effects were related to the eyes (irritation, lacrimation) and nose (a runny nose). This observation is in agreement with many other studies revealing that exposure of medical students to FA provoked eye irritation and resulted in itching, burning, soreness, pain, or conjunctivitis [4, 9, 13]. For example, Lang et al. found that FA increased nasal problems similar to that experienced by our students (dryness, bleeding) [25]. Akbar-Khanzadeh and Mlynek found a predominance of the eye irritation (in $82 \%$ of students) and nose problems (in 76\% of students) [26]. Usually eye and nasal irritation did not occur in parallel because the eyes are more sensitive; moreover, the experienced symptoms to some extent depended on individual sensitivity to chemicals/toxicants [25].

Formaldehyde is soluble in water; therefore it is rapidly absorbed in the respiratory and gastrointestinal tracts [6]. Low-level FA exposure resulted in the development of respiratory symptoms in $30-50 \%$ of our students. Throat dryness and upper respiratory tract problems were also reported by Onyije and Avwioro [9]. Wantke et al. [27] and Norbäck et al. [28] evidenced such symptoms in $45-50 \%$ of people. Digestive system problems including vomiting have also been experienced by our students. Exposure to formaldehyde and prolonged contact with FA may result in different gastrointestinal symptoms; even hemorrhage and ulceration of the digestive tract have been observed $[2,3]$.

In our study group, FA adverse effects on the skin were experienced to a lesser extent, which was pre- 

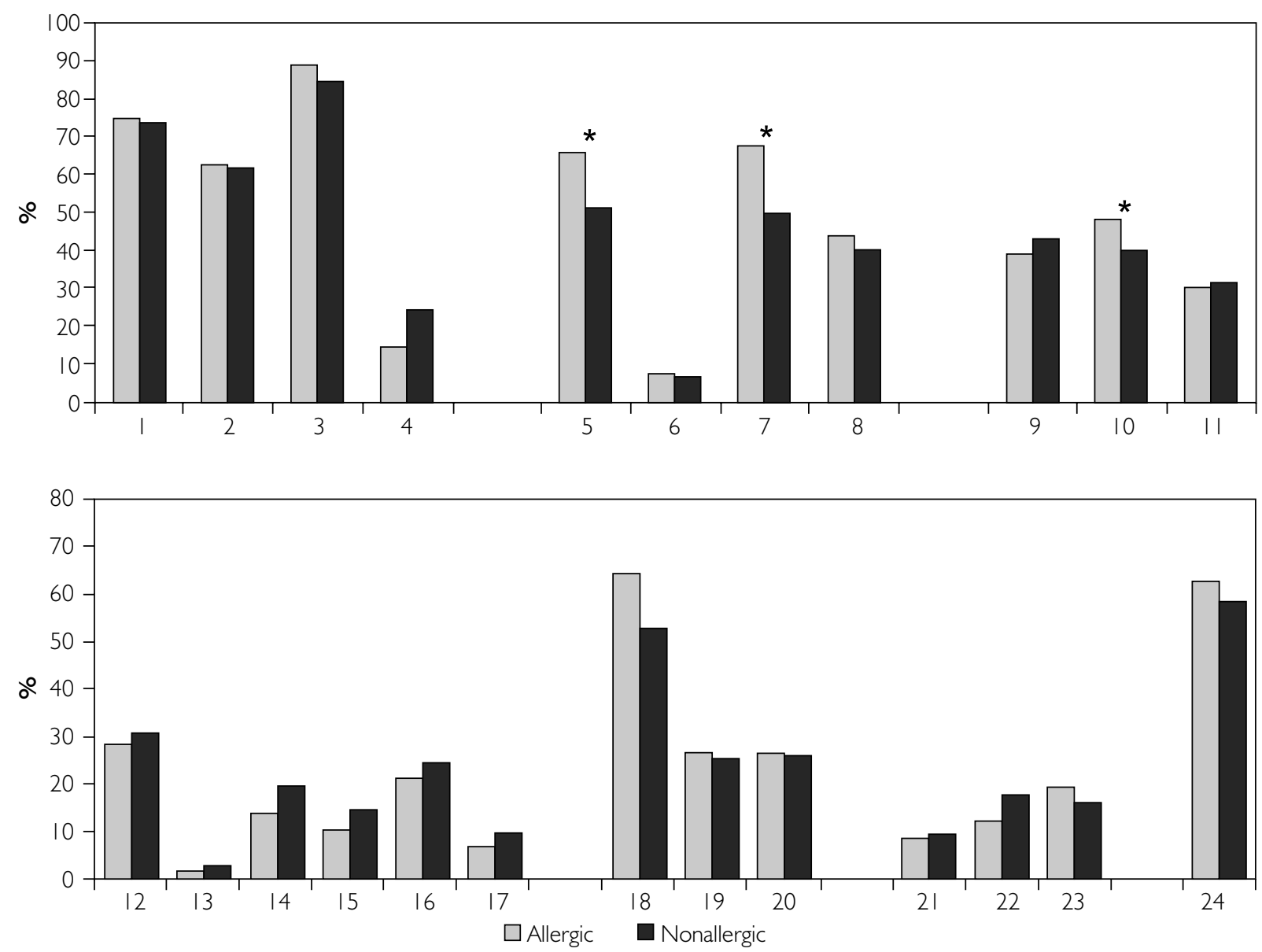

Figure I. Percentages of allergic and nonallergic students reporting subjective clinical symptoms after exposure to formaldehyde. Clinical symptoms related to the eyes: I - redness, 2 -dryness and itching, 3 - excessive lacrimation, 4 - deterioration in eyesight; clinical symptoms related to the nose: 5 - runny nose, 6 - nose bleeding, 7 - sneezing, 8 - alterations in odor perception; clinical symptoms related to the respiratory system: 9 - dry throat and throat irritation, 10 - cough, 1 I - respiratory distress; clinical symptoms related to the digestive system: 12 - nausea, 13 - vomiting, 14 - lack of appetite, I5 - Gl disturbances, 16 - increased appetite, 17 - excessive salivation; clinical symptoms related to the nervous system: 18 - headache, 19 - prolonged sleeping time, 20 - decreased perception; clinical symptoms related to the skin: 21 - rash, 22 - dryness and itching, 23 - redness; general symptom: 24 - fatigability. *Statistically significant difference between allergic and nonallergic students by Mann-Whitney $U$ test, $p<0.05$

Rycina I. Odsetek studentów medycyny z alergiq̨ oraz bez alergii w mywiadzie zgłaszających subiektywne objawy kliniczne po ekspozycji na formalinę. Objawy kliniczne dotyczq̨ce oczu: 1 - zaczerwienienie, 2 - suchość i świq̨d, 3 -wzmożone łzawienie, 4-zaburzenia widzenia; objawy kliniczne dotyczq̨ce nosa: 5 - katar, 6 - krwawienie, 7 - kichanie, 8 - zaburzenia węchu; objawy kliniczne dotyczq̨ce układu oddechowego: 9 - suchość i podrażnienie gardła, 10 - kaszel, II - zaburzenia oddychania; objawy kliniczne dotyczq̨ce układu pokarmowego: 12 - nudności, 13 - mymioty, 14 - brak apetytu, 15 - zaburzenia trawienia, 16 - wzmożony apetyt, 17 - zwiększone wydzielanie śliny; objawy kliniczne dotyczq̨ce układu nerwowego: 18 - ból głowy, 19 - wzmożona senność, 20 - obniżona percepcja; objawy kliniczne dotyczq̨ce skóry: 21 - wysypka, 22 - suchość i świąd, 23 - zaczerwienienie; objawy ogólne: 24 - zmęczenie. *Statystycznie istotne różnice pomiędzy studentami medycyny $z$ alergiq i bez alergii w mywiadzie w teście U Manna-Whitneya, $p<0,05$

sumably related to use of protective gloves, a common practice during contact with cadavers. In the literature, severe irritant effects of FA to the skin were reported, but after direct contact with formaldehyde containing liquids $[3,4]$. Skin irritation reported by some of our students may be related to a systemic allergic reaction, as most severe skin problems were reported by allergic students.

The students with allergy history reported more severe symptoms (compared to nonallergic students) related to eyes, nose, respiratory system, and skin. Allergic people are more sensitive to toxic substanc- es than nonallergic people; therefore they may be less able to tolerate even low formaldehyde concentrations and as a result of a lower sensitivity threshold develop symptoms more quickly. In allergic people, there is a risk of development of allergic sensitization to inhalant allergens, and symptoms commonly occur [29]. This may explain the more severe reaction of allergenic students in the form of nose and respiratory system related symptoms after FA inhalation, the main route of its exposure [30]. However, it is still unclear whether sensitization and FA-related symptoms are induced by formaldehyde-specific IgE [31, 
Table 2. Subjective symptoms of allergic and nonallergic students exposed to formaldehyde (FA) during cadaver dissection (mean values for Likert scale \pm SD)

Tabela 2. Subiektywne objawy u studentów medycyny z alergiq i bez alergii w mywiadzie po ekspozycji na formalinę podczas zajęć w prosektorium (wartości skali Likerta podane jako średnia \pm odchylenie standardowe)

\begin{tabular}{lccccccc} 
Students & \multicolumn{7}{c}{ Symptoms related to } \\
\cline { 2 - 8 } & Eyes* & Nose* & $\begin{array}{c}\text { Respiratory } \\
\text { system* }\end{array}$ & $\begin{array}{c}\text { Digestive } \\
\text { system }\end{array}$ & $\begin{array}{c}\text { Nervous } \\
\text { system }\end{array}$ & Skin* $^{*}$ & Fatigability \\
Allergic & $3.4 \pm 1.7$ & $2.9 \pm 1.3$ & $3.1 \pm 1.2$ & $2.6 \pm 1.3$ & $2.2 \pm 1.1$ & $2.8 \pm 1.3$ & $2.7 \pm 1.5$ \\
\hline Nonallergic & $2.6 \pm 1.4$ & $2.1 \pm 1.2$ & $2.0 \pm 1.3$ & $2.5 \pm 1.4$ & $2.0 \pm 1.2$ & $1.9 \pm 1.1$ & $2.5 \pm 1.2$ \\
\hline
\end{tabular}

*Statistically significant difference between allergic and nonallergic students by Mann-Whitney $U$ test, $p<0.05$.

Table 3. Subjective symptoms of male and female students exposed to formaldehyde (FA) during cadaver dissection (mean values for Likert scale \pm SD)

Tabela 3. Subiektywne objawy u studentów medycyny po ekspozycji na formalinę podczas zajęć w prosektorium w zależności od płci (wartości skali Likerta podane jako średnia \pm odchylenie standardowe)

\begin{tabular}{lccccccc} 
Students & \multicolumn{9}{c}{ Symptoms related to } \\
\cline { 2 - 7 } & Eyes* & Nose* & $\begin{array}{c}\text { Respiratory } \\
\text { system }\end{array}$ & $\begin{array}{c}\text { Digestive } \\
\text { system* }\end{array}$ & $\begin{array}{c}\text { Nervous } \\
\text { system }\end{array}$ & Skin & Fatigability \\
Male & $2.1 \pm 1.1$ & $1.9 \pm 1.0$ & $2.2 \pm 1.1$ & $1.9 \pm 1.0$ & $2.3 \pm 1.1$ & $2.6 \pm 1.2$ & $2.8 \pm 1.4$ \\
\hline Female & $2.7 \pm 1.3$ & $2.6 \pm 1.2$ & $2.0 \pm 1.0$ & $2.5 \pm 1.1$ & $2.2 \pm 1.0$ & $2.4 \pm 1.2$ & $2.6 \pm 1.3$ \\
\hline
\end{tabular}

*Statistically significant difference between male and female students by Mann-Whitney $U$ test, $p<0.05$

32]. Moreover, the role of other factors in the development of unpleasant symptoms during cadaveric dissection and formaldehyde exposure would not be excluded, for example, airborne allergenic pollen, smoking or stress-induced sensitization, as hypothesized by some authors [28, 33]. In fact, it has been documented that formaldehyde mixed with particles is more aggressive for organs' mucosa [34]. In a few particularly sensitive people, mucosa irritation in particular organs might induce mucosal hypersensitivity to histamine [13]. This mechanism may explain the presence of symptoms in students without allergy history or increased sensitivity of allergic students.

Our study further demonstrates more severe clinical manifestation to FA exposure in females. In general, the prevalence of many autoimmune and inflammatory diseases is higher in females than in males. Higher sensitization in females is associated with more pronounced B cell- and T cell-mediated immunity and stronger antibody responses to various foreign antigens $[35,36]$.

Unpleasant effects related to formaldehyde smell and FA-related symptoms did not discourage our students from coming to the dissecting room. They did not report problems with the class performance, or the perception of knowledge regarding anatomy. The formaldehyde smell and clinical symptoms did not have an impact on our students' attitudes. Hisamitsu et al. reported that the effects of medical students' exposure to FA during cadaver dissection are temporary, and usually clinical symptoms observed during the dissection course are transient and disappeared after a few days of exposure [13].

Given the fact that formaldehyde is toxic and is classified as a dangerous substance according to the EU Dangerous Preparations Directive (1999/45/ EC), it is of particular importance to stress that the adverse effects of FA on medical students can be improved by lowering the FA concentrations in anatomy dissection rooms. Primarily, student instructions before dissection, easy access to adequate personal protective equipment as well as different technological solutions are recommended as effective ways to minimize harmful FA effects [37]. Hence the Medical University of Lublin and the Department of Anatomy have established guidelines which recommend how to avoid exposure to formaldehyde in anatomy dissection rooms. The students have been informed about the potential health hazards of formaldehyde. In our department students are required to wear aprons or anatomy lab coat, lab shoes, hat, gloves and a face mask. Optionally students may use protective eyewear. It is accepted that medical face masks limit FA absorption considerably, reduce irritation and burning of the mucosa of the mouth and upper respiratory tract and decrease symptoms from the respiratory tract following inhalation [2, 38]. Also, gloves are recommended to protect against dermal contact with FA while dissecting cadavers [39].

The toxic effects could be reduced by lowering the concentrations of FA while controlling the airflow by opening windows or doors, and the use of ventilators 
[37]. In our laboratory rooms, the central ventilation system operates to circulate the air; the system brings fresh air into the laboratory room and allows one to control FA emission. The dissecting work table has a drainage system which allows reduced exposure to embalming solution and FA. These technological solutions are effective and meet the required standard criteria of the FA concentration in acceptable levels of formaldehyde in our laboratory rooms.

It is widely agreed that anatomy is a core knowledge for various medical specialists and other health care professionals $[10,40]$. Anatomy learned by cadaveric dissection has many proven benefits, i.e. students can explore the organization of the human body and investigate the functional anatomy. Due to technology development, the methods of teaching will undergo changes. The modern simulation technology allows one to perform virtual dissection and is being adopted by many of the world's medical schools [11, 40]. However, 'traditional' cadaveric dissection remains one of the most efficient methods of teaching anatomy for both undergraduate and postgraduate students. Cadaveric-based teaching is of particular importance during surgical training for residents and specialists in general surgery, urology, cardiothoracic surgery and neurosurgery, as well as radiologists and pathologists $[11,40,41]$.

Despite known toxic effects of FA in humans, it is still popular because of low costs and effectiveness. However, there has been a recent increase of interest in alternative conservatives for formaldehyde-based embalming. A possible choice is ethanol glycerin fixation with thymol or formaldehyde neutralization with ammonium carbonate to reduce the FA level. These methods are recommended for use in gross anatomy laboratories $[6,42]$.

\section{CONCLUSIONS}

In some medical students exposure to FA gas at concentrations of $0.47-0.57 \mathrm{mg} / \mathrm{m}^{3}$ may result in subjective sensory irritation, in different groups of medical students (male and female, allergic and nonallergic). Particularly unpleasant symptoms may be experienced by individuals with allergic history. Therefore, it is necessary to reduce formaldehyde levels further in the anatomy dissection laboratories.

\section{Conflict of interest}

The authors declare no conflict of interest.

\section{References}

1. Dixit D.: Role of standardized embalming fluid in reducing the toxic effects of formaldehyde. Indian J Forensic Med Toxicol 2008, 2, 1-6.
2. Kaden D.A., Mandin C., Nielsen G.D., Wolkoff P.: Formaldehyde. In: WHO Guidelines for indoor air quality: selected pollutants. World Health Organization, Geneva, 3, 2010.

3. Owen C.M., Beck M.H.: Occupational allergic contact dermatitis from phenol-formaldehyde resins. Contact Dermatitis 2001, 45, 294-295.

4. Takahashi S., Tsuji K., Fujii K., Okazaki F., Takigawa T., Ohtsuka A., et al.: Prospective study of clinical symptoms and skin test reactions in medical students exposed to formaldehyde gas. J Dermatol 2007, 34, 283-289.

5. Pazdrak K., Górski P., Krakowiak A., Ruta U.: Changes in nasal lavage fluid due to formaldehyde inhalation. Int Arch Occup Environ Health 1993, 64, 515-519.

6. Hendrick D.J., Lane D.J.: Occupational formalin asthma. Br J Ind Med 1977, 34, 11-18.

7. International Programme on Chemical Safety (IPCS): Formaldehyde. International Chemical Safety Card: 0275. WHO, Geneva 2004.

8. Vohra M.S.: Personal formaldehyde exposure level in the gross anatomy dissecting room at College of Medicine King Saud University Riyadh. Int J Occup Med Environ Health 2011, 24, 108-113.

9. Onyije F.M., Avwioro O.G.: Excruciating effects of formaldehyde exposure to students in gross anatomy dissection laboratory. Int J Occup Environ Med 2012, 3, 92-95.

10. Torres K., Torres A., Pietrzyk L., Lisiecka J., Błoński M., Bącik-Donica M., et al.: Simulation techniques in the anatomy curriculum: review of literature. Folia Morphol (Warsz) 2014, 73, 1-6.

11. Torres A., Staśkiewicz G.J., Lisiecka J., Pietrzyk Ł., Czekajlo M., Arancibia C.U., et al.: Bridging the gap between basic and clinical sciences: a description of a radiological anatomy course. Anat Sci Educ 2016, 9, 295-303.

12. Drake R.L., McBride J.M., Lachman N., Pawlina W.: Medical education in the anatomical sciences: the winds of change continue to blow. Anat Sci Educ 2009, 2, 253-259.

13. Hisamitsu M., Okamoto Y., Chazono H., Yonekura S., Sakurai D., Horiguchi S., et al.: The influence of environmental exposure to formaldehyde in nasal mucosa of medical students during cadaver dissection. Allergol Int 2011, 60, 373-379.

14. Baur X., Bakehe P., Vellguth H.: Bronchial asthma and COPD due to irritants in the workplace - an evidence-based approach. J Occup Med Toxicol 2012, 7, 19.

15. Lu Z., Li C.M., Qiao Y., Yan Y., Yang X.: Effect of inhaled formaldehyde on learning and memory of mice. Indoor Air 2008, 18, 77-83.

16. Casanova-Schmitz M., Starr T.B., Heck H.D.: Differentiation between metabolic incorporation and covalent binding in the labeling of macro molecules in the rat nasal mucosa and bone marrow by inhaled $14 \mathrm{C}$ and $3 \mathrm{H}$ formaldehyde. Toxicol Appl Phamacol 1984, 76, 26-44.

17. Vaughan T.L., Stewart P.A., Teschke K., Lynch C.F., Swanson G.M., Lyon J.L., et al.: Occupational exposure to formaldehyde and wood dust and nasopharyngeal carcinoma. Occup Environ Med 2000, 57, 376-384.

18. McLaughlin J.K.: Formaldehyde and cancer: a critical review. Int Arch Occup Environ Health 1994, 66, 295-301.

19. Shaham J., Bomstein Y., Gurvich R., Rashkovsky M., Kaufman Z.: DNA-protein crosslinks and p53 protein expression in relation to occupational exposure to formaldehyde. Occup Environ Med 2003, 60, 403-409.

20. Casanova-Schmitz M., Heck H.D.: Effects of formaldehyde exposure on the extractability of DNA from proteins in the rat nasal mucosa. Toxicol Appl Pharmacol 1983, 70, $121-132$. 
21. Laforest L., Luce D., Goldberg P., Bégin D., Gérin M., Demers P.A., et al.: Laryngeal and hypopharyngeal cancers and occupational exposure to formaldehyde and various dusts: a case-control study in France. Occup Environ Med 2000, 57, 767-773.

22. Yu I.T., Chiu Y.L., Wong T.W., Tang J.L.: Deaths from nasopharyngeal cancer among waiters and waitresses in Chinese restaurants. Int Arch Occup Environ Health 2004, 77, 499-504.

23. Bosetti C., McLaughlin J.K., Tarone R.E., Pira E., La Vecchia C.: Formaldehyde and cancer risk: a quantitative review of cohort studies through 2006. Ann Oncol 2008, 19, 29-43.

24. Collins J.J., Lineker G.A.: A review and meta-analysis of formaldehyde exposure and leukemia. Regul Toxicol Pharmacol 2004, 40, 81-91.

25. Lang I., Bruckner T., Triebig G.: Formaldehyde and chemosensory irritation in humans: a controlled human exposure study. Regul Toxicol Pharmacol 2008, 50, 23-36.

26. Akbar-Khanzadeh F., Mlynek J.S.: Changes in respiratory function after one and three hours of exposure to formaldehyde in non-smoking subjects. Occup Environ Med 1997, 54, 296-300.

27. Wantke F., Focke M., Hemmer W., Bracun R., Wolf-Abdolvahab S., Götz M., et al.: Exposure to formaldehyde and phenol during an anatomy dissecting course: sensitizing potency of formaldehyde in medical students. Allergy 2000, 55, 84-87.

28. NorbäckD., Björnsson E.,Janson C.,Widström J., Boman G.: Asthmatic symptoms and volatile organic compounds, formaldehyde, and carbon dioxide in dwellings. Occup Environ Med 1995, 52, 388-395.

29. Yoo Y., Perzanowski M.S.: Allergic sensitization and the environment: latest update. Curr Allergy Asthma Rep 2014, 14, 465.

30. Kriebel D., Myers D., Cheng M., Woskie S., Cocanour B.: Short-term effects of formaldehyde on peak expiratory flow and irritant symptoms. Arch Environ Health 2001, 56, 11-18.

31. Ohmichi K., Komiyama M., Matsuno Y., Sawabe Y., Miyaso H., Fukata H., et al.: Relationship between exposure

Submitted: 12 IV 2016

Accepted: $\quad 30$ VII 2016 to formaldehyde and immunoglobulin $\mathrm{E}(\mathrm{IgE})$ production during the gross anatomy laboratory. J Health Sci 2006, 52, 642-647.

32. Gu Y.H., Fujimiya Y., Kunugita N.: Long-term exposure to gaseous formaldehyde promotes allergen-specific IgE-mediated immune responses in a murine model. Hum Exp Toxicol 2008, 27, 37-43.

33. Bell I.R., Miller C.S., Schwartz G.E.: An olfactory-limbic model of multiple chemical sensitivity syndrome: possible relationships to kindling and affective spectrum disorders. Biol Psychiatry 1992, 32, 218-242.

34. Kleinman M.T., Mautz W.J.: The effects of exercise on dose and dose distribution of inhaled automotive pollutants. Cambridge, Mass.: Health Effects Institute; Research Report 1991, 45.

35. Whitacre C.C., Reingold S.C., O'Looney P.A.: A gender gap in autoimmunity. Science 1999, 283, 1277-1278.

36. Da Silva J.A.: Sex hormones and glucocorticoids: interactions with the immune system. Ann N Y Acad Sci 1999, 876, 102-117.

37. Mirabelli M.C., Holt S.M., Cope J.M.: Anatomy laboratory instruction and occupational exposure to formaldehyde. Occup Environ Med 2011, 68, 375-378.

38. Binding N., Witting U.: Exposure to formaldehyde and glutardialdehyde in operating theatres. Int Arch Occup Environ Health 1990, 62, 233-238.

39. Raja D.S., Sultana B.: Potential health hazards for students exposed to formaldehyde in the gross anatomy laboratory. J Environ Health 2012, 74, 36-40.

40. Sheikh A.H., Barry D.S., Gutierrez H., Cryan J.F., O'Keeffe G.W.: Cadaveric anatomy in the future of medical education: what is the surgeons view? Anat Sci Educ 2016; 9: 203-208.

41. Özcan S., Huri E., Tatar İ., Sargon M., Karakan T., Yağlı Ö.F., et al.: Impact of cadaveric surgical anatomy training on urology residents knowledge: a preliminary study. Turk J Urol 2015, 41, 83-87.

42. Hammer N., Loffler S.: Ethanol-glycerin fixation with thymol conservation: a potential alternative to formaldehyde exposure. Anat Sci Edu 2012, 5, 225-233. 